\title{
THE EFFECTS RESULTING FROM THE APPLICATION OF THE CONCEPT OF THE SUSTAINABLE DEVELOPMENT OF RURAL TOURISM ON STARA PLANINA
}

\author{
Mladjan Maksimović ${ }^{1}$, Darjan Karabašević2 ${ }^{2}$ Miodrag Brzakovićc ${ }^{3}$, Pavle Brzakovićc
}

\begin{abstract}
The development of rural tourism on Stara planina (Old Mountain) has a positive impact on the economic development of the local communities in the area. However, if an adequate program of the sustainable development of tourism on Stara planina were made, that would also have positive effects as an accompanying factor contributing to the development of rural tourism. In particular, the results would show that there is a need for the preservation of the quality of the environment and the development of all resources, especially with respect to the realization of an economic profit. The aim of the paper is to detect the extent to which the effects arising from the development of rural tourism depend on the implementation of the program of the sustainable tourism development of the mountain. The method that makes the realization of a causal connection between these two phenomena possible is the linear regression analysis. The purpose of the regression analysis is to determine the shape of such a connection, i.e. the dependence between the observed phenomenon, by applying a mathematical formula and a range of corresponding assumptions. Therefore, it best describes the quantitative relationship between the variation in the observed phenomenon of reality, as well as the agent that serves to evaluate the predictive value and the dependent variable against the desired value of the explanatory variables or the effects resulting from the development of rural tourism on Stara planina.
\end{abstract}

1 Mladjan Maksimović Ph.D., Assistant Professor, Faculty of Management, Economics and Finance, University Business Academy in Novi Sad, Jevrejska Street no. 24, 11000 Belgrade, Phone: +381 64 1479793, E-mail: mladjan.maksimovic@mef.edu.rs

2 Darjan Karabašević Ph.D., Assistant Professor, Faculty of Management, Economics and Finance, University Business Academy in Novi Sad, Jevrejska Street no. 24, 11000 Belgrade, Phone: +381 60 3383333, E-mail: darjan.karabasevic@mef.edu.rs.

3 Miodrag Brzaković Ph.D., Associate Professor, Faculty of Management, Economics and Finance, University Business Academy in Novi Sad, Jevrejska Street no. 24, 11000 Belgrade, Phone: +381 64 1820103, E-mail: miodrag.brzakovic@mef.edu.rs.

4 Pavle Brzaković MA., Faculty of Management, Economics and Finance, University Business Academy in Novi Sad, Jevrejska Street no. 24, 11000 Belgrade, Phone: +381 64 3290255, E-mail: pavlebzakovic@yahoo.com.

EP 2017 (64) 4 (1595-1606) 
Key words: Stara planina, rural tourism, development effects, sustainable development JEL: Q10, Z30, Z32

\section{Introduction}

The rural areas still account for a significant part of the territory of the Republic of Serbia - namely 85\% (Bogdanov, 2007) and quite a substantial part of the Serbian population still lives there $-42 \%$. Therefore, the issue of rural development and the welfare of the rural population is one of the main issues of the overall sustainable development of the Republic of Serbia. The rural areas are being seriously faced with a large number of problems, such as strong depopulation, economic underdevelopment, growing poverty and generally unfavorable conditions for life. In the past few decades, rural tourism, as well as commercial tourism, has been accompanied by many environmental, social and cultural undesired consequences; thus, there is an imposed need for the framing of this activity by applying the concepts of sustainable development. Although the modern world is faced with responsibility and the awareness of the fact that the planet must be preserved for the present and future generations, it is necessary to reconcile human needs with the preservation of nature, because it is the obligation of the present generation to leave a chance to posterity, at least to the extent that they themselves have had.

The current generation has the right to resources and a healthy environment, but it must not compromise the same rights for generations to come (Markovic, Pejanović, 2012; Jovicic, 2002). Sustainable tourism means an industry that has a minimal impact on the local culture and environment, which simultaneously promotes the creation of new jobs, the earning of adequate wages and the protection of ecosystems, (http:// $w w w$.logos.org.rs). There is no single definition of the sustainable development of rural tourism; it can, however, be said that the sustainable development of rural tourism implies the observance of the general principles of sustainable development and ethical changes with all the participants in the tourism process. Although the concern for sustainable development is regularly presented as the foundation of the modern planning and management of tourist destinations, the question of how it is applied in practice is regularly raised (Ruhanan, 2012).

In Johannesburg in 2002, Serbia set sustainable tourism as an example of sustainable development, i.e. it presented tourism based on the concept of sustainable development (Zivkovic, 2013). According to Zivkovic, the goal of the program is to develop the legal and policy frameworks in order to support the diversification of the rural economy through tourism and to contribute to achieving the Millennium Development Goals at the national level, better connections and the organization of rural tourism by improving the capacity of local actors to provide services and production in accordance with the national strategy at the local level. 


\section{Literature Review}

In managing the sustainable development of rural tourism, tourism organizations play a very important role since their basic task is to foster co-operation among rural tourism actors in different destinations (Pechlaner et al., 2012). The introduction of external control and the management of tourist facilities in registered destinations also play an important role in local socio-economic development (Akama, Chieti, 2007). When the family households engaged in rural tourism are concerned, there is a need for such cooperation, as well as the creation of a partnership network, which is certainly an interesting phenomenon, because this form of cooperation is far more effective than the traditional application of the consortium. In this way, there is a popular phenomenon known as the "integration flock", which is an extremely important resource when the development of rural tourism is in question (Krajnović et al., 2011).

The appearance of a distance in cooperation observed between individual family households and the relevant Ministry may serve as a guide to the state-level institutions that, using modern management tools and modern technology, connect with family households so as to be better acquainted with their development problems (Cawley, Desmond, 2007).

It is noted that such a significant form of cooperation exists with the institutions at the local level; it is weaker with those at the regional level and the weakest with the institutions at the level of the state (Clarke, 1996). This finding is consistent with the guidelines for the development of rural tourism and it is defined by the Directives of the European Commission (IQM) model, where the word about the strategic planning and overall management of the development of rural tourism, as well as the other forms of tourism, must come from the base or the local communities where rural tourism is being developed (Gilbert, 1989). The sustainable development of rural tourism is now an effective tool for the development of local communities; however, the tourism industry very often has no significant role at all in all of this (Akama \& Chieti, 2007).

Today, modern tourists are viewed as the whole chain of the entire tourist offer, from the moment of booking tickets to their returning home. It is, therefore, necessary to introduce the concept of the TQM (Total Quality Management) as a management tool, which would be an imperative of modern business. One of the suggestions in this case was the construction of the appropriate facilities that, together with natural and cultural resources, represent the key attractions and improve the quality of tourists' stays in the country (Cvijanovic, 2014).

The development of the programs of the sustainable development of rural tourism on Stara planina and the general tourist offer, which would provide a wide range of diverse content, should certainly be implemented in order to meet tourists' needs. In this context, it is necessary that aggressive marketing, advertising and market performance should be implemented in order to set the goal and make both domestic and foreign tourists become familiar with the outstanding natural beauty offered by rural tourism on Stara planina. The aggressive marketing policy oriented towards the development of 
this type of tourism must be consistent with the implementation of the design ideas of the tourist offer in general (Scheyvens, 2007) because tourist propaganda is one of the instruments of the tourism policy, applied in order to achieve certain goals. In that way, there would certainly be an increased fluctuation of tourists as a result of the propaganda policy, which in this case is a potential engine for the economic development (Brown, Hall, 2008) of the rural areas on Stara planina. In the opinion of the majority, the task of the local governments, as well as that of many tourist organizations and the nongovernmental sectors, was to be maximally involved in this industry not only as the actors, but also as the backing bearers of the activities of propaganda. The members of the rural households that would be included in tourism, together with the accompanying infrastructure and the related activities, do not have to look for additional jobs outside their place of residence. The modern management of the household can strategically allocate the existing capacity with the aim of meeting tourists' current and future needs (Scoones, 2009; Biddulph, 2015).

The development of rural tourism on Stara planina also implies making the rural areas closer to the local community in order to protect the living environment. The strengthening of human resources in the tourism industry is also an important strategic direction in the development of rural tourism on Stara planina. The basic characteristic of employment in the tourism sector is the need for a large number of unskilled or semiskilled, seasonal workers because there is a great need for the jobs that do not require professional qualifications. On the other hand, such a low qualification structure shows that it takes a relatively little time for their professional training and development.

Human resources in rural tourism are characterized by a high level of the age structure of the employees. Simultaneously, it reflects the state of the economy and society because all those who cannot follow the trends of modern knowledge and education are left without work engagement in other activities and, in this way, they seek salvation in the tourism industry. On the other hand, rural tourism also requires dynamism, enthusiasm and professional young people ready to respond and adapt to every challenge. The positive perception of a tourist destination and the tourist's pleasant first impression can only be encouraged by young people, those who are ambitious, professional, knowledgeable of several foreign languages and who have all the relevant information necessary for tourists.

The favorable geographical position of Stara planina provides recognizable importance for the development of rural tourism on the mountain, with the goal of the further economic and ecological development of the rural area and the local community. Organizing natural and cultural heritage into one territorial system is one of the factors that drive the development of a region through achieving integration between culture, the environment, characteristic and sustainable development, where the dynamic and longterm effects of an action taken by institutional organizations can effectively manage the development of rural tourism and the natural environment (Mitchell \& Ashley, 2010). The development of agriculture, as an important part of the regional economy, is very important because healthy agricultural households can respond to the tourist demand 
related to rural tourism. Promoting agricultural products in direct contact with tourists may not guarantee a direct economic benefit, but it does certainly provide a basis for comparing the prices and the quality of agricultural products to other rural destinations (Gibson, 2009; Lacher, Nepal, 2010; Sharpley, 2002; Walpol, Goodwin, 2000). This leads to the improvement of economic conditions and the development of the economic and non-economic activities that meet the tourist's needs, simultaneously being the key challenge for tourism service providers in rural areas, i.e. in small rural communities (Zapata et al., 2011).

\section{Research Materials and Methods}

The aim of this paper is to determine the extent to which the realization of a program of the sustainable development of the tourism of Stara planina depends on the effects of the development of rural tourism. The research study was carried out in the territory of Eastern Serbia, in the region of the foothills of Stara planina, in the period from April 15, 2017 to May 15, 2017. The research was done anonymously and the questionnaires were used as the research tool, the number of the validly filled ones being 250 . The proposed effects that would result from the realization of the programs of the sustainable development of the tourism of Stara planina are as follows:

- The preservation of the quality of the environment and all the developmental resources.

- Making economic profits.

- The preservation of the social integrity of the local community.

- The preservation of the affirmation of the cultural integrity of Stara planina.

- Increased employment in the tourism sector.

- The preservation of the rural environment and the cultural heritage.

- Motivating the local population to stay in the countryside.

A five-step Likert scale was applied to the gradation of the received responses and the data processing was carried out by applying the SPSS 23.0 software package. Based on the data obtained from the conducted descriptive analysis, the determinants are defined as the survey segments. Therefore, several variables are aggregated into one single determinant that is the bearer of all of the information related to the responses of each survey segment using the arithmetic mean derived from the data on the same scale of measurement. In this way, we now obtained the descriptive statistical parameters that explain the form, the distribution and the heterogeneity/homogeneity of the data. This is a quantitative continuous random variable - the determinant, which was subject to checking whether that the same belongs to the normal distribution of the random variable. This check was performed by the application of the universal KolmogorovSmirnov statistical test.

After the said test had been applied, the new random variable-determinant was found not to fulfill the regularity of the random variable distribution, so it was necessary to 
apply one of the basic transformation methods, the so-called "degree" transformation, after which the complete analytics and exploration for the so-called transformed random variable-determinant was repeated.

High heterogeneity was eliminated by the data transformation, so the determinant took on the appearance of the so-called Gaussian bell, as can be seen from the following tables and charts.

Table 1. The descriptive statistics of the determinants of the sustainable development of the tourism program of Stara planina

\begin{tabular}{|c|l|l|r|r|}
\hline \multicolumn{2}{|c|}{ Descriptive statistics } & \multicolumn{1}{c|}{ Statistics } & \multicolumn{1}{c|}{$\begin{array}{c}\text { Post-transformation } \\
\text { statistics }\end{array}$} \\
\hline \multirow{4}{*}{$\begin{array}{c}\text { Program of the } \\
\text { sustainable developmen } \\
\text { of the tourism of Stara } \\
\text { planina }\end{array}$} & Arithmetic mean & 3.7592 & 14.6074 \\
\cline { 2 - 5 } & $\begin{array}{l}95 \% \text { average trust } \\
\text { interval }\end{array}$ & Low & 3.6806 & 14.0627 \\
\cline { 2 - 5 } & Average mean & High & 3.8377 & 15.1521 \\
\cline { 2 - 5 } & Variations & 3.9216 & 15.3787 \\
\cline { 2 - 5 } & Standard deviation & 0.478 & 22.983 \\
\cline { 2 - 5 } & Minimum & 0.69114 & 4.79410 \\
\cline { 2 - 5 } & Maximum & 1.37 & 1.88 \\
\cline { 2 - 5 } & Asymmetry & 4.90 & -0.039 \\
\cline { 2 - 5 } & Equalization & 0.746 & -0.383 \\
\hline
\end{tabular}

Source: Author's calculation based on the survey data

Table 1 reveals the fact that the average value of the determinant is 3.7592 , where the confidence interval ranges from 3.6806 to 3.8377 , with the standard deviation of less than 1 , thus indicating the moderate heterogeneity of the data. The average minimum value is 1.37 and the maximum is 4.90 . The coefficient of the spinning asymmetry partially increased, as can be seen on the chart of the normal distribution of the frequency of the branch-sheet model, Fig. 1.

The normality test (Table 2) verified the validity of the results of the sustainable development program, where, based on the obtained results presented in the table, it was noted that the legality with respect to the parametric statistical tests had not been fulfilled. After that, the degree of transformation was established as the first and basic transformation, where a new determinant with the average value of 14.6074 was obtained in that way, within the confidence interval ranging from 14.0662 to 15.1521 , the standard deviation being 4.79410 , where the values of the asymmetry were reduced, which fulfills the lawfulness for the parametric statistical tests. The graphs in Figure 1 show that the obtained results are arranged according to the Gaussian curve. 
Table 2. The normality test for the values of the results of the sustainable development of the tourism program of Stara planina

\begin{tabular}{|c|c|c|c|}
\hline \multirow{2}{*}{} & \multicolumn{3}{|c|}{ Kolmogorov-Smirnov } \\
\cline { 2 - 4 } & Statistic & df & Sig. \\
\hline Sustainable development program & 0.107 & 300 & 0.000 \\
\hline Sustainable development program TP & 0.061 & 300 & 0.058 \\
\hline
\end{tabular}

Source: Author's calculation based on the survey data

Figure 1. The normal frequency distribution of the branch-sheet model for the sustainable program of the development of Stara planina

\begin{tabular}{|ll|}
\hline 2.00 & 1.99 \\
\hline 5.00 & 2.11111 \\
\hline 2.00 & 2.33 \\
\hline 8.00 & 2.44445555 \\
\hline 9.00 & 2.666667777 \\
\hline 10.00 & 2.8888999999 \\
\hline 16.00 & 3.0000000000111111 \\
\hline 20.00 & 3.22222222222333333333 \\
\hline 24.00 & 3.4444444444555555555555555 \\
\hline 29.00 & 3.6666666666666777777777777777777 \\
\hline 38.00 & 3.8888888899999999999999999999999999999999 \\
\hline 45.00 & 4.000000000000011111111111111111111111111111111 \\
\hline 39.00 & 4.22222333333333333333333333333333333333333 \\
\hline 30.00 & 4.444455555555555555555555555555 \\
\hline 12.00 & 4.666677777777 \\
\hline 7.00 & 4.8888899 \\
\hline
\end{tabular}

Source: Author's calculation based on the survey data

\section{Research Results}

The regression analysis is the method that provides the accomplishment of the causal link. Bearing in mind the purpose of the regression analysis between the observed appearances by applying the mathematical formula and an array of the adequate assumptions, it describes the best quantitative dependence between the variations of the observed appearances in reality, as well as the means that serve to evaluate and foresee changeable and variable values for the desirable value. 
Table 3. The correlation coefficients between the effects of the development of tourism on Stara planina and the programs for the sustainable development of rural tourism

\begin{tabular}{|c|c|c|c|}
\hline $\begin{array}{c}\text { Simple linear } \\
\text { correlation }\end{array}$ & $\begin{array}{c}\text { Determinant } \\
\text { coefficient }\end{array}$ & $\begin{array}{c}\text { Fixed determinant } \\
\text { coefficient }\end{array}$ & Standard deviation \\
\hline 0.478 & 0.229 & 0.226 & 3.95653 \\
\hline
\end{tabular}

Source: Author's calculation based on the survey data

Table 3 clearly states the simple linear correlation coefficient as the relative measurement $(0.478)$ that indicates a certain positive link between the variables. The determination coefficient is 0.229 and the fixed determination coefficient is 0.226 . The surging effects of the development of rural tourism are somewhat dependent on the realization of the program of the sustainable development of the tourism of Stara planina and in this case it is $23 \%$. Whether this is a significant indicator or not can be concluded from the following table. The standard error of the assessment for the tested variable is smaller than the sample error, which is indicative of the fact that there is a justification of the given model.

Table 4. The justification of the regression model via the Anova test

\begin{tabular}{|l|c|c|c|c|c|}
\hline $\begin{array}{c}\text { Justification of } \\
\text { the model }\end{array}$ & $\begin{array}{c}\text { Square } \\
\text { amount }\end{array}$ & df & $\begin{array}{c}\text { Square } \\
\text { average }\end{array}$ & F test & $\begin{array}{c}\text { Deviation } \\
\text { probability }\end{array}$ \\
\hline Regression & 1384.137 & 1 & 138.137 & 88.420 & 0.000 \\
\hline Residual & 4664.931 & 298 & 15.654 & & \\
\hline Total & 6049.068 & 299 & & & \\
\hline
\end{tabular}

Source: Author's calculation based on the survey data

Table 4. accounts for the variability explained by the justified determinant, which is statistically significant, which is confirmed by the statistical $\mathrm{F}$ test.

Table 5. The statistical parameters of the regression analysis of the sustainable development program

\begin{tabular}{|c|c|c|c|c|c|}
\hline \multirow{2}{*}{$\begin{array}{c}\text { Statistical parameters } \\
\text { of the model }\end{array}$} & \multicolumn{2}{|c|}{$\begin{array}{c}\text { Non-Standardized } \\
\text { coefficients }\end{array}$} & $\begin{array}{c}\text { Standardized } \\
\text { coefficients }\end{array}$ & \multirow{2}{*}{ t } & $\begin{array}{c}\text { Deviation } \\
\text { probability }\end{array}$ \\
\cline { 2 - 4 } & B & S.D & Beta & & \\
\hline Intercept/Constant & 8.292 & 0.734 & & 11.303 & 0.000 \\
\hline Inc. Sust. Dev. & 0.449 & 0.048 & 0.478 & 9.403 & 0.000 \\
\hline
\end{tabular}

Source: Author's calculation based on the survey data

Based on Table 5, a conclusion can be drawn that the intercept of the regression line is statistically significant based on the t test and the probability of a deviation is far less than 0.05 . The positive incline (the sustainable development of the tourism of Stara planina) is also statistically significant with respect to the effects surging from rural tourism, which is also visible on the scatter diagram below. Namely, we can ascertain 
that the program is highly significant because not only by producing it, but also by having the same implemented a rise in the effects surging from the development of the tourism of Stara planina will be achieved.

The scatter diagram (Figure 2) indicates the existence of a quantitative accordance between the variations of the observed appearances. Namely, by the implementation of the program, the effects of the development grow, which confirms the existence of a direct link between the observed appearances.

Figure 2. The scatter diagram for the program of the sustainable development of the tourism of Stara planina

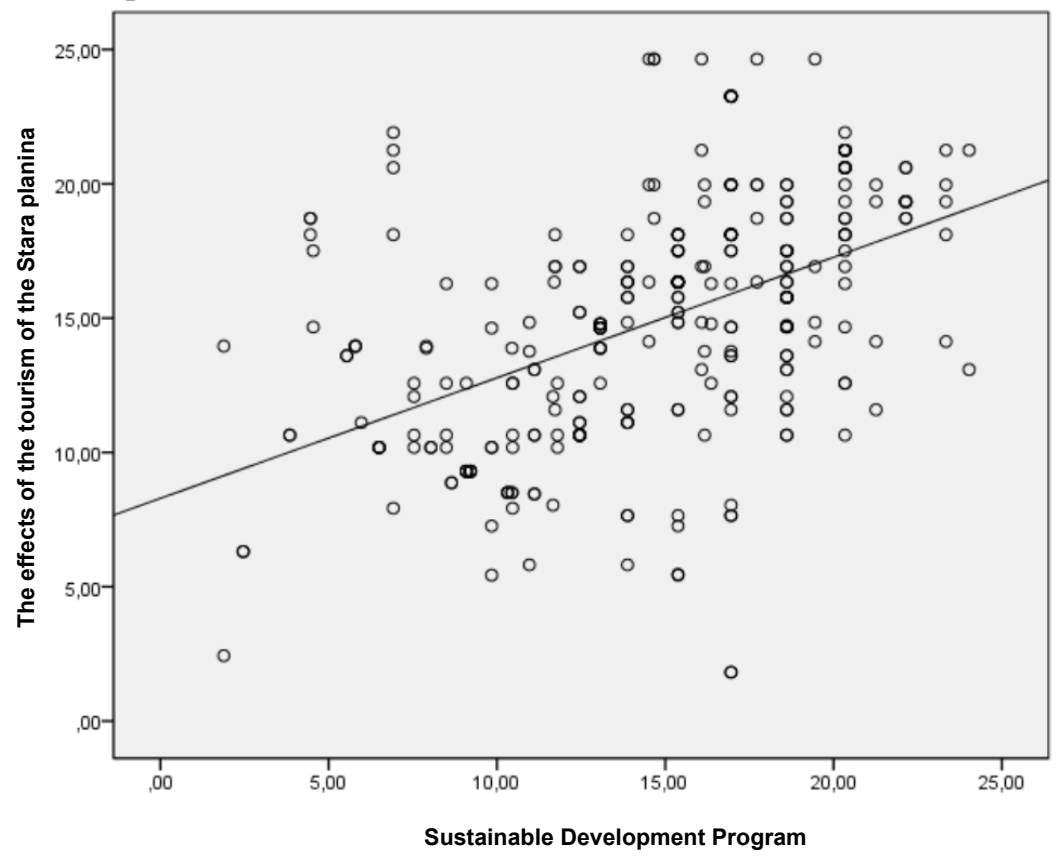

Source: Author's calculation based on the survey data

\section{Conclusion}

The development of the rural tourism of Stara planina (Old Mountain) depends on many factors that might have an influence in different ways. The surging effects of rural tourism are: the quality preservation of the environment, higher employment in the tourism sector and, therefore, the preservation and achievement of an economic profit and local social integrity. The improvement of tourism development is measured by those same effects and, therefore, their realization requires the drafting of a program of the sustainable development of Stara planina, according to the survey conducted among the people from within the region, as rural tourism is an adequate alternative to mass tourism primarily because of the fact that it is focused on attracting tourists who want to spend their time in nature. Based on the indicators obtained by the statistical test, as the scatter diagram shows, a fact can be established that the program of the sustainable development of the 
tourism of Stara planina is highly significant, because only the very drafting of the same, as well as its implementation, would lead to an increase in the effects that are created by development of rural tourism on Stara planina. The positive inclination of the regression line is indicative of the fact that there is an interdependence between the effects created by the development of rural tourism on Stara planina and the program of the sustainable development of the tourism of Stara planina.

\section{Literature}

1. Akama, J.S., Kiet,i D. (2007). Tourism and Socio-economic Development in Developing Countries: A Case Study of Mombasa Resort in Kenya, Journal of Sustainable Tourism, Vol. 15, No. 6, pp. 735-748.

2. Biddulph, R. (2015). Limits to mass tourism's effects in ruralperipheries, Annals of Tourism Research, Vol. 50., pp. 98-212.

3. Bogdanov, N. (2007). Mala ruralna domaćinstva u Srbiji i ruralno nepoljoprivradna ekonomija, Beograd, UNPD.

4. Brown, F., \& Hall, D. (2008). Tourism and development in the Global South: The issues. Third World Quarterly, Vol. 29, pp. 839-849

5. Cawley, M., Desmond, A. G. (2007). Integrated rural tourism: Concepts and Practice, Annals of Tourism Research Vol. 35, No. 2, pp. 316-337.

6. Clarke, J. (1996). Farm accommodation and the communication mix, Tourism Management, Vol. 17, No. 8, pp. 611-616.

7. Cvijanović, D. (2014). Turističko tržište u dunaskom regionu. Monografija, institut za ekonomiku poljoprivrede, Beograd.

8. Gibson, C. (2009). Geographies of tourism: Critical research on capitalism and local livelihoods. Progress in Human Geography, Vol. 33, pp. 527-534.

9. Gilbert, D. (1989), Rural tourism and marketing: Synthesis and new ways of working, Tourism Management, Vol. 10, No. 1, pp. 39-50.

10. http://www.logos.org.rs

11. Jovičić, D. (2002). Menadžment turističkih destinacija, Želnid, Beograd.

12. Krajnović, A., Čičin-Šain D., Predovan M. (2011). Strateško upravljanje razvojem ruralnog turizma - problemi i smjernice. Oeconomica Jadertina Vol. 1, No. 1, pp. 30-45

13. Lacher, G. R., \& Nepal, S. K. (2010). From leakages to linkages: Locallevel strategies for capturing tourism revenue in northern Thailand. Tourism Geographies, Vol. 12, pp. 77-99.

14. Marković, S., Pejanović, Lj. (2012). Zaštita životne stedine u politici održivog razvoja. Fakultet za pravne i poslovne studije, Novi Sad.

15. Mitchell, J., \& Ashley, C. (2010). Tourism and poverty reduction: Pathways to prosperity (1st ed.). London: Earthscan 
16. Pechlaner, H., Volgger, M., Herntrei, M. (2012). Destination management organizations as interface between destination governance and corporate governance, Anatolia: An International Journal of Tourism and Hospitality Research, Vol. 23, No. 2. pp. 151-168.

17. Ruhanan, L. (2012). Developing a strategic vision: integration principles of sustainable development in planning tourist destinations, Acta Turistica, Vol. 24, No. 2, pp 149-176.

18. Scheyvens, R. (2007). Exploring the tourism-poverty nexus. Current Issues in Tourism, Vol. 10, pp. 231-254.

19. Scoones, I. (2009). Livelihoods perspectives and rural development. Journal of Peasant Studies, Vol. 36, pp. 171-196.

20. Sharpley, R. (2002). Rural tourism and the challenge of tourism diversification: The case of Cyprus. Tourism Management, Vol. 23, pp. 233-244.

21. Walpole, M. J., \& Goodwin, H. J. (2000). Local economic impacts of dragon tourism in Indonesia. Annals of Tourism Research, Vol. 27, pp. 559-576.

22. Zapata, M. J., Hall, C. M., Lindo, P., \& Vanderschaeghe, M. (2011). Can community-based tourism contribute to development and poverty alleviation? Lessons from Nicaragua. Current Issues in Tourism, Vol. 14, pp. 725-749.

23. Živković, B.(2013). Ekonomski aspekti uticaja turizma na ekonomiju ruralnih regija, Ecologica Vol. 20, No. 71, pp. 541-544. 


\title{
EFEKATI KOJI NASTAJUPRIMENOM KONCEPTA ODRŽIVOG RAZVOJA RURALNOG TURIZMA NA STAROJ PLANINI
}

\author{
Mladjan Maksimović, Darjan Karabašević ${ }^{6}$, Miodrag Brzaković ${ }^{7}$, Pavle Brzaković ${ }^{8}$
}

\begin{abstract}
Sažetak
Razvoj ruralnog turizma na Staroj planini pozitivno utiče na ekonomski razvoj lokalnih zajednica u tom području. Međutim, sa adekvatnim programom održivog razvoja turizma Stare planini nastali bi i pozitivni efekti kao prateći faktor razvoja ruralnog turizma. Posebni bi rezultati pokazali kod Očuvanje kvaliteta životne sredine $i$ svih razvojnih resursa, a naročito ostvarenje ekonomskih profita. Cilj rada je da detektuje u kojoj meri od realizacije programa održivog razvoja turizma Stare planine, zavise efekti koji nastaju razvojem ruralnog turizma. Metoda koja omogućava da se ostvare uzročno-posledične veze između ovih pojava je linearna regresiona analiza. Svrha regresione analize je utvrditi oblik veze, odnosno zavisnost između posmatranih pojava kroz matematičku formulu i niza odgovarajućih pretpostavki. Zbog toga ona najbolje opisuje kvantitativnu zavisnost između varijacija posmatranih pojava u realnosti kao sredstva koje nam služi da se ocene i predvide vrednosti zavisne promenljive za željene vrednosti objašnjavajuće promenljive, odnoisno efekata koji nastaju razvojem ruralnog turizma na Staroj planini.
\end{abstract}

Ključne reči: Stara planina, Rurali turizam, efekti razvoja, održivi razvoj

5 Doc. dr Mladjan Maksimović, Fakultet za primenjeni menadžment, ekonomiju i finansije, Beograd, Univerzitet Privredna akademija Novi Sad, Jevrejska 24, 11000 Beograd, Telefon: +38164 1479793, E-mail: mladjan.maksimovic@mef.edu.rs

6 Doc. dr Darjan Karabašević, Fakultet za primenjeni menadžment, ekonomiju i finansije, Beograd, Univerzitet Privredna akademija Novi Sad, Jevrejska 24, 11000 Beograd, Telefon: +381 60 3383333, E-mail: darjan.karabasevic@mef.edu.rs.

7 Prof. dr Miodrag Brzaković, Fakultet za primenjeni menadžment, ekonomiju i finansije, Beograd, Univerzitet Privredna akademija Novi Sad, 24, 11000 Beograd, Telefon: +381 64 1820103, E-mail: miodrag.brzakovic@mef.edu.rs.

8 Asistent, Pavle Brzaković MA., Fakultet za primenjeni menadžment, ekonomiju i finansije, Beograd, Univerzitet Privredna akademija Novi Sad, Jevrejska 24, 11000 Beograd, Telefon: +38164 3290255, E-mail: pavlebzakovic@yahoo.com. 
ECONOMICS OF

AGRICULTURE

\section{CONTENT}

1. Adriana Radosavac, Desimir Knežević

ECONOMIC IMPORTANCE OF USE

OF PESTICIDES IN WHEAT PRODUCTION . . . . . . . . . . . 1323

2. Berhe Gebregewergs, Muuz Hadush

DOES CLIMATE CHANGE AFFECT PRICE OF VEGETABLES:

EVIDENCE FROM TIGRAI, NORTHERN MOST ETHIOPIA. . . . .1335

3. Grujica Vico, Aleksandra Govedarica-Lučić, Zoran Rajić, Radomir Bodiroga, Ivan Mičić, Silvija Zec Sambol, Marija Mičić

MULTI ATTRIBUTE ASSESSMENT APPROACH

IN VEGETABLE PRODUCTION . . . . . . . . . . . . . . 1355

4. Igor Trandafilović, Vesna Conić, Aleksandra Blagojević

IMPACT OF DEMOGRAPHIC FACTORS ON

ENVIRONMENTALLY CONSCIOUS PURCHASE BEHAVIOUR. . .1365

5. Imre Milán Harcsa

STUDY ON THE POTENTIAL OF SUBCONTRACT

PALINKA DISTILLATION . . . . . . . . . . . . . . 1379

6. Jelena Andrašić, Vera Mirović, Nada Milenković, Branimir Kalaš, Miloš Pjanić

IMPACT OF TAKEOVER PROCESS ON EMPLOYEES -

EVIDENCE FROM FOOD, RETAIL AND FINANCIAL SECTOR . . .1393

7. Jelena Birovljev, Danilo Đokić, Bojan Matkovski, Žana Kleut

ECONOMIC PERFORMANCES OF AGRICULTURE

OF CEFTA AND FORMER CEFTA COUNTRIES . . . . . . . . . . 1413

8. Jelena Marković, Svetlana Stevović

SUSTAINABILITY OF CHEMICAL SOIL QUALITY

IN SOUTHERN MORAVA RIVER VALLEY

IN CORELLATION WITH THE FLOODING $\ldots \ldots \ldots \ldots \ldots$ 
9. Mile Peševski, Zoran Milovančević

THE CHANGES IN THE USAGE OF AGRICULTURAL LAND

IN EASTERN REGION OF REPUBLIC OF MACEDONIA

BETWEEN $1991-2030 \ldots \ldots$. . . . . . . . . . . . . . . . . . . . . . .

10. Odjuvwuederhie Emmanuel Inoni, 'Oraye Dicta Ogisi, Felix Odemero Achoja

PROFITABILITY AND TECHNICAL EFFICIENCY IN HOMESTEAD

CATFISH PRODUCTION IN DELTA STATE, NIGERIA . . . . . . . 1449

11. Olja Munitlak - Ivanović, Jovan Zubović, Petar Mitić

RELATIONSHIP BETWEEN SUSTAINABLE DEVELOPMENT AND

GREEN ECONOMY - EMPHASIS ON GREEN FINANCE

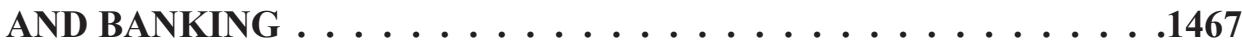

12. Petar Munćan, Dragica Božić

FARM SIZE AS A FACTOR OF EMLOYMENT AND INCOME

OF MEMBERS OF FAMILY FARMS . . . . . . . . . . . . . 1483

13. Rade Popović, Mira Kovljenić

EFFICIENCY OF WHEAT PRODUCTION ON FARMS

IN THE REPUBLIC OF SERBIA . . . . . . . . . . . . . . . . . . . . . . . . .

14. Radovan Damnjanović, Snežana Krstić, Milena Knežević, Svetislav Stanković,

Dejan Jeremić

THE DISCRIMINANT ANALYSIS APPLIED TO THE

DIFFERENTIATION OF SOIL TYPES . . . . . . . . . . . . 1513

15. Slavica Otović, Dunja Demirović, Kristina Košić, Aleksandra Vujko

FOSTERING ENTERPRENUERSHIP AT HIGH SCHOOLS:

A CASE OF RURAL AREAS IN VOJVODINA (SERBIA) . . . . . . .1523

16. Vladimir Ilić, Ivan Bauer, Anastazija Tanja Đelić, Aleksandar Nešković

INSTITUTIONAL SUPPORT FOR STRENGTHENING

ENTREPRENEURSHIP IN AGRICULTURAL PRODUCTION

OF THE REPUBLIC OF SERBIA . . . . . . . . . . . . . . . . . . . . . . . .

17. Boro Krstić, Zorica Vasiljević, Miroslav Nedeljković

INSURANCE CONTRACT AS THE BASIS FOR THE SAFETY OF

AGRICULTURAL PRODUCERS IN THE REPUBLIC OF SRPSKA • . 1555

18. Dejan Sekulić, Aleksandar Petrović, Vladimir Dimitrijević

WHO ARE WINE TOURISTS? AN EMPIRICAL INVESTIGATION

OF SEGMENTS IN SERBIAN WINE TOURISM . . . . . . . . . . . . . 
19. Milan Beslać, Ćorić Goran

FINANCIAL AND PRODUCTION ASPECTS OF GENETICALLY MODIFIED ORGANISMS $\ldots \ldots \ldots \ldots \ldots \ldots \ldots \ldots \ldots$

20. Mlađan Maksimović, Darjan Karabašević, Miodrag Brzaković, Pavle Brzaković THE EFFECTS RESULTING FROM THE APPLICATION OF THE CONCEPT OF THE SUSTAINABLE DEVELOPMENT OF RURAL TOURISM ON STARA PLANINA . . . . . . . . . . . . . . . .1595

21. Vesna Popović, Predrag Vuković, Milivoje Ćosić FOOD SAFETY AND QUALITY POLICY IN THE REPUBLIC OF SERBIA . . . . . . . . . . . . . . . . 1607

22. Radovan Pejanović, Danica Glavaš-Trbić, Mirela Tomaš-Simin PROBLEMS OF AGRICULTURAL AND RURAL DEVELOPMENT IN SERBIA AND NECESSITY OF NEW AGRICULTURAL POLICY . . . .1619

23. Saša Marković, Slavoljub Vujović, Aleksandar Damnjanović MARKETING AND HIGHER EDUCATION CONDITION IN SERBIA . . . . . . . . . . . . . . . . 1635

24. Semir Vehapi, Marina Milanović THE EFFECT OF MARKET ORIENTATION ON BUSINESS PERFORMANCE OF SERBIAN ORGANIC PRODUCERS . . . . . 1651

25. Suad Bećirović, Šemsudin Plojović, Enis Ujkanović, Senadin Plojović CHALLENGES AT STARTING AN AGRIBUSINESS IN THE HILLY MOUNTAINOUS REGIONS OF SOUTHWEST SERBIA . . . . . . . .1669

26. Vladimir Zakić, Vlado Kovačević, Jelena Damnjanović SIGNIFICANCE OF FINACIAL LITERACY FOR THE AGRICULTURAL HOLDINGS IN SERBIA . . . . . . . . . . 1687

27. Željko Bjelajac, Marijana Dukić Mijatović, Željko Vojinović PROTECTION OF LAND IN THE REPUBLIC OF SERBIA AND ECOLOGICAL SECURITY WITH REGARD TO STRATEGIC AND LEGAL FRAMEWORKS . . . . . . . . . .1703 